\title{
The adsorptive potential of chicken egg shells for the removal of oxalic acid from wastewater
}

\author{
Muhammad I kram ${ }^{1,2}$, Afrasiab Ur Rehman ${ }^{1}$, Sharafat Ali ${ }^{1}$, Sher Ali ${ }^{1}$, Syed UI Hasnain Bakhtiar ${ }^{1}$, \\ Sultan Alam ${ }^{2}$
}

1. Key Laboratory of Functional Inorganic Materials Chemistry, Heilongjiang University, Harbin, China. 2. Department of Chemistry University of Malakand, KPK, Malakand, Pakistan.

Correspondence: Sultan Alam. Address: Department of Chemistry University of Malakand, KPK, Malakand, Pakistan. Email: drsultanalam@yahoo.com

Received: January 27, 2016

DOI : $10.5430 /$ jbei.v2n2p118
Accepted: March 6, $2016 \quad$ Online Published: April 13, 2016

URL: http://dx.doi.org/10.5430/jbei.v2n2p118

\section{Abstract}

Chicken egg shells were grinded and sieved to an exact particle size of 125 micron and treated with excess aqua regia and n-hexane to remove inorganic and organic impurities. Adsorption of oxalic acid from waste water was studied on treated powder egg shells by kinetics and batch adsorption techniques at different temperatures, $20^{\circ} \mathrm{C}, 30^{\circ} \mathrm{C}$ and $40^{\circ} \mathrm{C}$. The samples were characterized by BET surface area, scanning electron microscopy (SEM), and Fourier Transform Infra-red Spectroscopy (FTIR) and energy dispersive spectroscopy (EDS) techniques. The amount of acid adsorbed was determined with respect to initial acid concentration, equilibrium time and different acid concentration manually by titration method. Intra-particle diffusion, Elovich and Bhangam models were used for adsorption kinetics and thermodynamic parameters $\Delta \mathrm{H}^{\neq}, \Delta \mathrm{S}^{\ddagger}$ and $\Delta \mathrm{E}^{\neq}$were calculated. The results obtained showed that adsorption process was spontaneous and entropy of adsorption had negative value. Freundlich, Langmuir, Tempkin and Harkins-Jura linear equations were used to investigate adsorption isotherms. This work will provide feasible routes for waste water treatment.

\section{Key words}

Egg shells, Titration, Oxalic acid, Adsorption kinetics, Adsorbent

\section{I ntroduction}

Urbanization and industrialization all around the world has affected the quality of ground and surface water as numerous untreated poisonous effluents are discharged continuously. Environmental pollution caused by the discharge of untreated poisonous effluents is a major concern of $21^{\text {st }}$ century ${ }^{[1-4]}$. The industrial effluents cause serious environmental issues because of their adverse effects on the aquatic and terrestrial life as water eutrophication by these substances prevents the penetration of sunlight necessary for photosynthesis ${ }^{[5]}$. The effluents generated contain toxic substances including dyes, acids, carcinogenic metals, alkalis and aromatic amines which affect the quality, aesthetic merit, transparency and penetration of sun light required for aquatic bodies. The presence of these substances increases the risk of cancer in human being and is very difficult to remove under aerobic conditions.

Among these substances, dicarboxylic acids are the main concern as they are soluble in water ${ }^{[6]}$. Bacteria, fungi, algae, higher plants and some animals secrete organic acids. Important man made sources which participate in the release of 
organic acids include different products of agriculture, food processing, organic waste, sewage sludge and land fill leachate. As a consequence, organic acids are unfit in ecosphere. Acidic water is dangerous for living organisms on land, aquatic-life and for other material like concrete pipe. The presence of acids also increases the solubility of heavy metals. Oxalic acid in waste water is important constituent responsible for unpleasant smell ${ }^{[7,8]}$.

Various wastewater treatment technologies are based on the process of coagulation, flocculation, biodegradation, adsorption, membrane separation, ion exchange, oxidation and selective bio-adsorbents for the elimination of these materials. Because of high cost and disposal problems, many of the conventional methods have not been applied at large scale in different industries. Adsorption has been found to be superior to other techniques in terms of low-cost, flexibility and simplicity of design, ease of operation and insensitivity to toxic pollutants ${ }^{[9]}$. In adsorption, different adsorbents used include activated carbon ${ }^{[10]}$, zeolite ${ }^{[1]}$, clays ${ }^{[12]}$, silica beads ${ }^{[13]}$, and polymeric acids ${ }^{[14]}$ etc. However, due to high cost, these materials cannot be justified to cope with pollution and therefore, research has been directed towards methods of treatment using locally available low-cost natural materials such as biopolymers ${ }^{[10]}$.

In the present work, powder egg shells have been used successfully for the removal of oxalic acid from wastewater. Egg shells are waste materials from hatcheries, households and fast food industries and can be readily collected in plenty. It is about $11 \%$ of the total egg weight and consists of about $95 \%$ calcium carbonate and $5 \%$ of others materials such as $\mathrm{Al}_{2} \mathrm{O}_{3}$, $\mathrm{SiO}_{3}, \mathrm{~S}, \mathrm{Cl}, \mathrm{Cr}_{2} \mathrm{O}_{3}$ and $\mathrm{MnO}_{3}$. Egg shells are waste product as about $28 \%$ of the total eggs are used commercially in egg products and their disposal contributes to environmental pollution because these cannot be used traditionally ${ }^{[15-17]}$. These wastes are directly disposed without any pretreatment; challenges associated with disposal include cost, availability of disposal sites, odor, flies and abrasiveness. However, these egg shells can be used as an excellent adsorbent because of their porous nature; about 700 to 1,700 pores are present on the surface an egg shell ${ }^{[18,19]}$. The egg shells are also attractive as adsorbent due to their good mechanical properties and thermal stability ${ }^{[20]}$ and already used as adsorbent for the removal of heavy metals ${ }^{[21]}$, phenolic compounds ${ }^{[22]}$, dyes ${ }^{[23]}$, and pesticides ${ }^{[24]}$.

\section{Materials and methods}

\subsection{Sample preparation (Adsorbent)}

Chicken egg shells collected from bakery shops (Mardan, Pakistan) were washed with distilled water several times and dried in the oven. The dried samples were grinded into powder form and sieved to an exact particle size of 125 micron by Glenammer Sieves, Ayrshire. Scotland. Half of the powder sample was treated with excess of $0.2 \mathrm{M}$ solution of $\mathrm{HCl}$ and HNO3 solution for 24 hours to remove inorganic materials from the sample and again washed thoroughly with distilled water until its $\mathrm{pH}$ reached 7 . Then the sample was treated with $\mathrm{n}$-hexane for 24 hours to remove organic impurities and dried in oven at $105^{\circ} \mathrm{C}$. The sample was reffered as modified egg shell and used as such.

\subsection{Oxalic acid (Adsorbate)}

All solutions were prepared in distilled water. Oxalic acid was used as adsorbate. First stock solution of acid was prepared, and then from this solution, different other working solutions were prepared by dilution method.

\section{Characterizations}

The surface area of powder egg shells was determined by Bruner-Emmet-Teller, BET N2-adsorption. The experiment was performed manometrically at $-196^{\circ} \mathrm{C}$ using surface area and pore size analyzer (Model: Quanachrome NOVA 2200).

FTIR spectra of the samples were found by 8201PC Shimadzu and FTCOM-1 computer control disc unit using dried KBr pellet technique. Different ratios of $\mathrm{KBr}$ were used to obtain an acceptable resolution spectrum. 
Scanning electron micrographs (SEM) of the samples was carried out with the help of SEM-Model-JSM-5910, Japan JEOL, by mounting the sample on aluminum $(1 \mathrm{~cm} \times 0.25 \mathrm{~cm})$ while energy dispersive spectrum (EDS) was taken with the help of EDS-INCA 200 Oxford for metal detection.

For the calculation of moisture contents in egg shell, one gram of powder sample was taken in a china dish, covered it with a watch glass and then heated in a vacuum oven at $105^{\circ} \mathrm{C} \pm 2^{\circ} \mathrm{C}$ for 2 hours. The china dish was cooled in desiccators and weighed to calculate the percent weight loss (see Table 1).

Table 1. Characteristics of treated egg shells sample

\begin{tabular}{ll}
\hline Parameters & Results \\
\hline Particle size & $125 \mu \mathrm{m}$ \\
$\%$ Ash content & $4.3 \%$ \\
$\%$ Moisture content & $1 \%$ \\
\hline
\end{tabular}

In order to determine the ash contents in egg shells, one gram of powder sample was taken in a porcelain crucible and ignited at $600^{\circ} \mathrm{C}$ in a Muffle furnace with partially opened door. After ignition the crucible was allowed to cool to room temperature naturally and percent weight loss was calculated (see Table 1).

\section{Adsorption study}

\subsection{Time equilibration}

The raw $(0.2 \mathrm{~g})$ and treated powder egg shells $(0.2 \mathrm{~g})$ were taken in each of different reagent bottles and $20 \mathrm{~cm}^{3}$ of oxalic acid solution was added to each of them. Two different initial concentration of oxalic acid was taken for each sample and the reagent bottles were shaken in a thermostat water bath shaker for different time periods of $0.5,1,2,4,6$ and 8 hours at $250^{\circ} \mathrm{C}$. The slurry obtained after specified time was filtered, $\mathrm{pH}$ was noted before and after experiment. The filtrate was titrated against standard $\mathrm{NaOH}$ solution to determine change in acid concentration. The amount of acid adsorbed $\left(C_{\varnothing}\right.$ $\mathrm{mol} \cdot \mathrm{g}^{-1}$ ) was calculated by Eq (1):

$$
C_{\emptyset}=\frac{\left(C_{0}-C_{\sigma}\right)}{S} V
$$

where $C_{\emptyset}$ is the amount of acid adsorbed, $C_{0}$ is the initial concentration and $C_{\sigma}$ is equilibrium concentration of the acid, $V$ is volume of acid taken and $S$ is the adsorbent weight.

\subsection{Adsorption kinetics study}

The adsorbent $(0.2 \mathrm{~g})$ and $20 \mathrm{~cm}^{3}$ of adsorbate solution were mixed in reagent bottle. The reaction mixture was shaken in thermostat water bath shaker at $20^{\circ} \mathrm{C}, 30^{\circ} \mathrm{C}$ and $40^{\circ} \mathrm{C}$ from 5 to 30 minutes. The solution was filtered and the filtrate was analyzed against standard $\mathrm{NaOH}$ solution to determine the change in acid concentration. $\mathrm{pH}$ was noted before and after filtration. The amount of acid adsorbed was calculated by Eq (1).

\subsection{Adsorption isotherm study}

The adsorbent $(0.2 \mathrm{~g})$ was mixed with $20 \mathrm{~cm}^{3}$ of adsorbate solution in a reagent bottle. The mixture was shaken in the shaker at $20^{\circ} \mathrm{C}, 30^{\circ} \mathrm{C}$ and $40^{\circ} \mathrm{C}$ for 2 hours. The mixture was filtered and the clear filtrate was analyzed against standard $\mathrm{NaOH}$ solution. 


\section{Results and discussion}

\subsection{BET surface area}

To determine the BET surface area of treated egg shells the Bruner-Emmet-Teller procedure ${ }^{[21]}$ was used. It is based on multilayer adsorption of nitrogen gas on adsorbent surface and investigates the micro porous surface of adsorbent. The linear form of BET equation is as follows:

$$
\frac{1}{V\left[\left(P_{0} / P^{-1}\right)\right]}=\frac{C-1}{V_{m} V}\left(\frac{P}{P_{0}}\right)+\frac{1}{V_{m} V}
$$

where $P$ and $P_{0}$ are diffusion pressure of adsorbate, $V$ is the quantity of adsorbed gas on the surface of adsorbent, $V_{m}$ is the monolayer adsorbed $\mathrm{N}_{2}$ and $C$ is constant defined by Eq (3):

$$
C=\frac{E_{1}-E_{L}}{R T}
$$

where $E_{1}$ is the heat of adsorption for the first adsorbed layer while $E_{L}$ for the onward layers.

Eq (2) is used for adsorption isotherm by plotting $1 / V\left[\left(P_{0} / P-1\right)\right] v s$. Slope and intercept is used for the calculation of monolayer adsorbed gas $\left(\mathrm{N}_{2}\right), V_{m}$ and $C$ can be obtained through the following equations:

$$
\begin{gathered}
V_{m}=\frac{1}{A+I} \\
C=\frac{A+1}{I}
\end{gathered}
$$

The specific and total surface area was calculated by the following equations:

$$
\begin{aligned}
& S_{\text {total }}=\frac{V_{m} N_{A} \sigma}{M} \\
& S_{B E T}=\frac{S_{\text {total }}}{\alpha}
\end{aligned}
$$

$V_{m}$ is the molar volume of $\mathrm{N}_{2}$ gas adsorbed; $N_{A}$ is the Avogadro's number, $\sigma$ is the cross section of $\mathrm{N}_{2}$ and $\alpha$ is mass of adsorbent.

The BET surface area of the sample were determined by plotting $1 / W\left[\left(P_{0} / P-1\right)\right] v s . P / P_{0}$ of the adsorption of $\mathrm{N}_{2}$ and the changes in surface area of treated sample were determined Table 2.

Table 2. BET surface area $\left(\mathrm{m}^{2} \cdot \mathrm{g}^{-1}\right)$ of egg shells sample

\begin{tabular}{|l|l|}
\hline \multirow{4}{*}{ Adsorbent } & Egg shells sample \\
\cline { 2 - 2 } & Treated \\
\cline { 2 - 2 } & 273 \\
\hline
\end{tabular}

The result obtained shows that the surface area of adsorbent increases when treated with chemicals. During the chemical treatment the surface of the sample clean and the other impurities were removed and the surface becomes exposed for attachment of oxalic acid molecule. At high temperature the surface of the sample with non-polarity is another reason for high surface area is due to the fact that these groups present on the surface and leaving the surface for homogeneous ${ }^{[23]}$. 

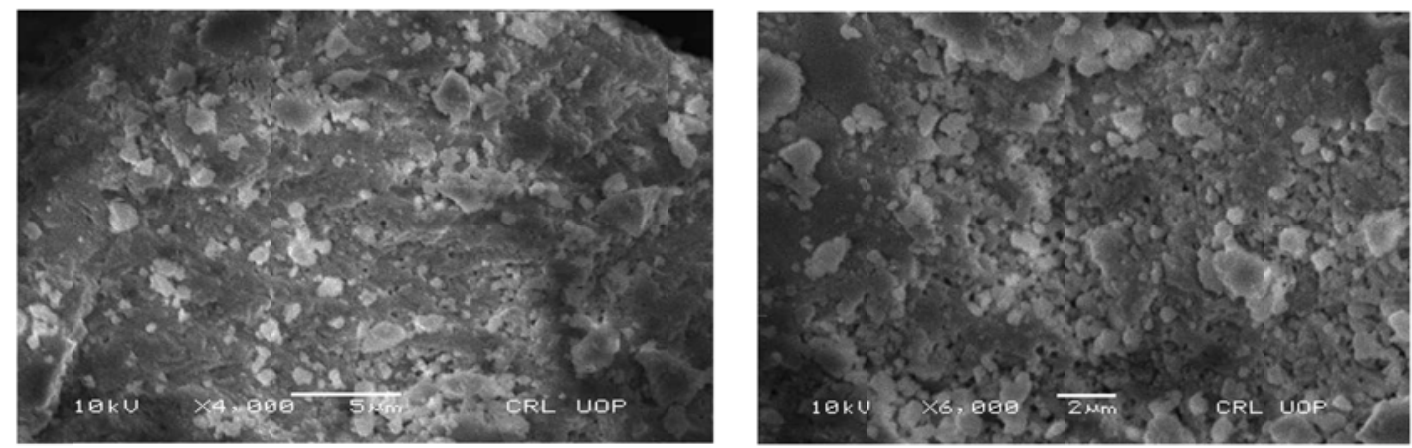

Figure 1. SEM images at different resolutions $(\times 4000, \times 6000)$ of treated egg shells sample

\subsection{SEM/ EDS analysis}

To identify the characteristic morphology of samples, SEM of egg shells was determined. The SEM images clearly show that pores of different shapes and size are present on the surface of the samples (see Figure 1). EDS spectra shows that modified egg shells composed of calcium, oxygen and carbon elements (see Figure 2 and Table 3).

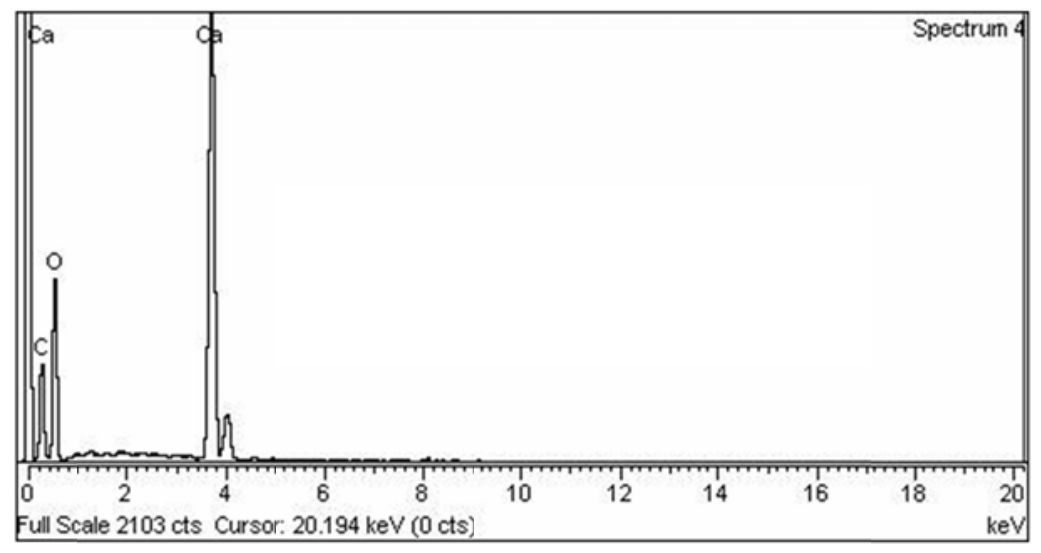

Figure 2. EDS of treated egg shells sample

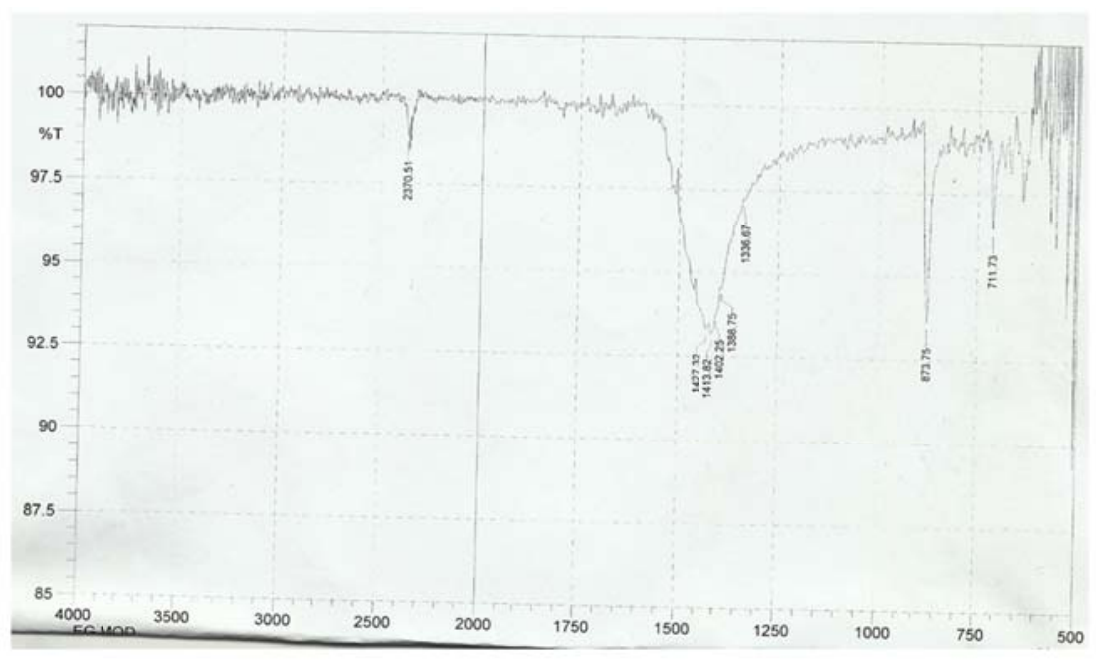

Figure 3. FTIR spectrum of treated egg shells sample 
Table 3. Elemental composition of treated Egg shells sample by EDS

\begin{tabular}{lll}
\hline Element & Weight (\%) & Atomic (\%) \\
\hline Carbon $(\mathrm{C})$ & 13.82 & 21.59 \\
Oxygen $(\mathrm{O})$ & 53.83 & 63.18 \\
Calcium $(\mathrm{Ca})$ & 32.34 & 15.20 \\
\hline
\end{tabular}

\subsection{FTI R analysis}

FTIR spectra of treated egg shell are given in Figure 3. The region $1,427.32 \mathrm{~cm}^{-1}$ to $1,336.67 \mathrm{~cm}^{-1}$ in the spectra shows the presence of carbonyl group, $\mathrm{CH}$ and NO stretching group ${ }^{[26]}$. The treated samples of egg shells show bands at $1,413.82 \mathrm{~cm}^{-1}, 1,336.67 \mathrm{~cm}^{-1}, 873.75 \mathrm{~cm}^{-1}$ and $711.73 \mathrm{~cm}^{-1}$. The peak at $873.75 \mathrm{~cm}^{-1}$ is due to the presence of NO stretching group. The band at $2,370.51 \mathrm{~cm}^{-1}$ is due to $\mathrm{C}-\mathrm{H}$ stretching mode.

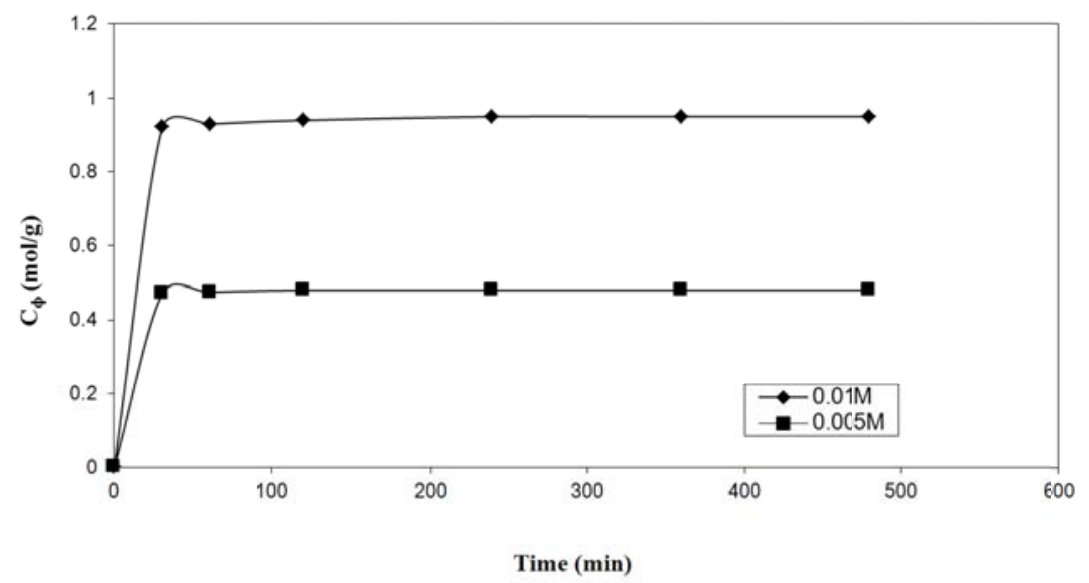

Figure 4. Equilibration time for the adsorption of oxalic acid on treated egg shells sample

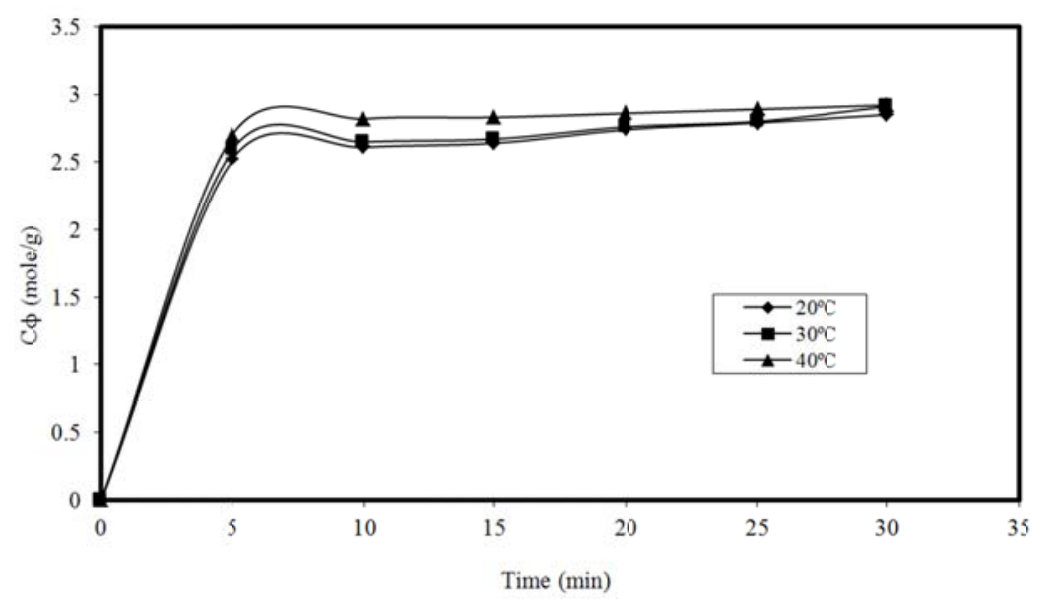

Figure 5. Adsorption kinetics for the adsorption of oxalic acid on treated egg shells sample

\subsection{Adsorption study}

\subsubsection{Equilibrium time and adsorption kinetics}

Equilibrium time for the adsorption of oxalic acid on samples was studied at room temperature $\left(25^{\circ} \mathrm{C}\right)$ for the period of $0.5,1,2,4,6$ and 8 hours. Figure 4 shows that the equilibrium was reached after 2 hours which indicates that 2 hours is the 
optimum time for complete surface coverage. From equilibrium time study, adsorption kinetics of acid at $20^{\circ} \mathrm{C}, 30^{\circ} \mathrm{C}$ and at $40^{\circ} \mathrm{C}$ temperature was determined as shown in Figure 5. It is observed that in the initial 15 minutes, adsorption was fast due to the availability of more sorption sites and decreases gradually as more and more surface is occupied by the adsorbed molecules. It is also observed that the sorption of acids increases on the surface of adsorbent with an increase in temperature. This shows that the process is an endothermic process.

\subsubsection{Adsorption kinetic linear equations}

From the sorption of oxalic acid on powder egg shell samples, the rate constant was calculated by using the first order rate equation ${ }^{[27]}$ :

$$
\ln C_{\varnothing}=\ln C_{0}-k_{a d} t
$$

$C_{0}$ is initial and $C_{\varnothing}$ is the equilibrium concentration of acids $\left(\mathrm{mol} \cdot \mathrm{dm}^{-3}\right)$ and $k_{a d}$ is rate constant. A plot of $C_{\varnothing}$ versus $t$ at different temperatures as shown in Figure 5 gives the rate constant. It is clear from Table 4 that the values of rate constant increases with an increase in temperature. From the first order rate equation the value of regression coefficient $\left(R^{2}\right)$ is in between (0.91-0.99) which is closer to 1 and shows best agreement with literature.

Table 4. Comparison of the parameters of rate equations for the oxalic acid onto treated egg shells sample

\begin{tabular}{|c|c|c|c|c|}
\hline \multirow{2}{*}{ Kinetic Model } & \multirow{2}{*}{ Parameter } & \multicolumn{3}{|c|}{ Adsorption temperatures } \\
\hline & & $20^{\circ} \mathrm{C}$ & $30^{\circ} \mathrm{C}$ & $40^{\circ} \mathrm{C}$ \\
\hline \multirow{2}{*}{ Elovich } & $\mathrm{A}_{\mathrm{E}}(\mathrm{g} / \mathrm{mg})$ & 5.549 & 6.172 & 8.833 \\
\hline & $\mathrm{R}^{2}$ & 0.9724 & 0.976 & 0.9824 \\
\hline \multirow{3}{*}{ Intraparticle diffusion } & $\mathrm{C}(\mathrm{mg} / \mathrm{g})$ & 2.2823 & 2.3548 & 2.589 \\
\hline & $\mathrm{K}_{\mathrm{id}}\left(\mathrm{mg} / \mathrm{gmin}^{1 / 2}\right)$ & 0.1014 & 0.0929 & 0.0613 \\
\hline & $\mathrm{R}^{2}$ & 0.9793 & 0.9207 & 0.9272 \\
\hline \multirow{3}{*}{ Bangham } & A & -0.6188 & -0.6808 & -0.6987 \\
\hline & $\mathrm{K}_{0}$ & 10.179 & 10.547 & 6.632 \\
\hline & $\mathrm{R}^{2}$ & 0.8601 & 0.7399 & 0.9116 \\
\hline
\end{tabular}

Energy of activation was calculated from Arrhenius straight line equation ${ }^{[27]}$ which is as follows:

$$
\ln \frac{K_{2}}{K_{2}}=\frac{E_{a}}{R}\left(\frac{T_{2}-T_{1}}{T_{1} T_{2}}\right)
$$

$K_{2}$ and $K_{1}$ are rate constants, $E_{a}$ is the activation energy, $R$ is gas constant and $T$ is absolute temperature. The activation energies calculated for acid adsorbed on raw and treated powder egg shells are given in Table 4 . The activation energies $\left(5.997 \mathrm{~kJ} \cdot \mathrm{mol}^{-1}\right)$ of treated egg shells are comparatively low indicating that the process of adsorption is governed by weak physical forces as reported by earlier research workers ${ }^{[28]}$. Similarly other thermodynamic parameters like enthalpy of activation $\left(\Delta \mathrm{H}^{\ddagger}\right)$ and entropy of activation $\left(\Delta \mathrm{S}^{\ddagger}\right)$ were calculated from activation energy and are given in Table 4 . The positive value of $\Delta \mathrm{H}^{\ddagger}$ shows that adsorption of oxalic acid on egg shell is endothermic nature in nature. Similarly the negative value of $\Delta \mathrm{S}^{\neq}$shows the affinity of adsorbate towards powder egg shells.

\subsubsection{Elovich model}

Elovich model equation is expressed in linear form as follows ${ }^{[29,30]}$ :

$$
C_{\varnothing}=\frac{1}{A} \ln (A B)+\frac{1}{A} t
$$

When $C_{\varnothing}$ was plotted against Int, a straight line was obtained with slope equal to $1 / A$, and intercept $\frac{1}{A} \ln (A B)$ as shown in Figure 6. It is clear that the value of "A" decreases with increasing temperature from $20^{\circ} \mathrm{C}$ in to $40^{\circ} \mathrm{C}$. The results show that 
adsorption of acid increases on the surface of adsorbent at high temperature. The $\mathrm{R}^{2}$ value is about equal to 1 reveals that the model is best fitted for the adsorption of acid on the surface of bio-sorbent powder sample.

Figure 6. Elovich plots for the adsorption of oxalic acid on treated egg shells

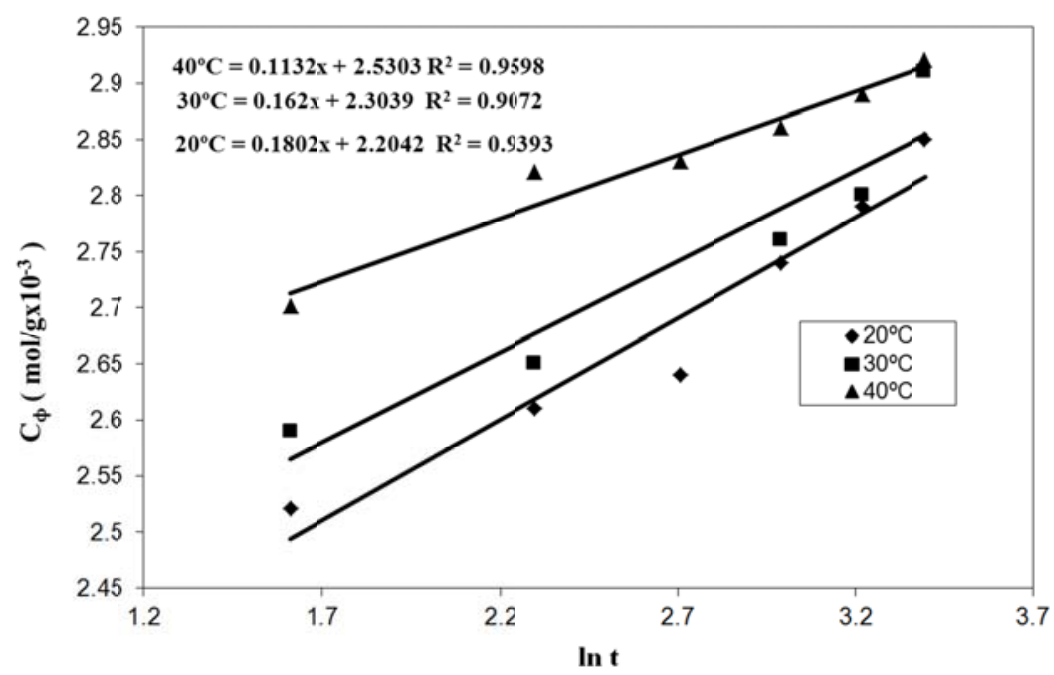

\subsubsection{Bangham equation}

Linear form of Bangham equation is follows:

$$
\log \left(\log \frac{C_{0}}{C_{0}-C_{\sigma}}\right)=\log \frac{K W}{2.303 V}+\alpha \log t
$$

Where $C_{0}$ is the initial concentration of acid in solution, $V$ is volume of solution, $W$ is the weight of adsorbate and $C_{\sigma}$ is the amount adsorbed and $t$ is time. By using the slope and intercept of linear plots (see Figure 7), to calculate the value of $\mathrm{K}_{0}$ and A (see Table 5). The results show that the value of A gradually decreases with the increasing of shaking temperature, while the value of $\mathrm{K}_{0}$ increases with the increasing of temperature. It also shows that the adsorption of acid into the pores of the adsorbent is well controlled, suitable and important process ${ }^{[31,32]}$.

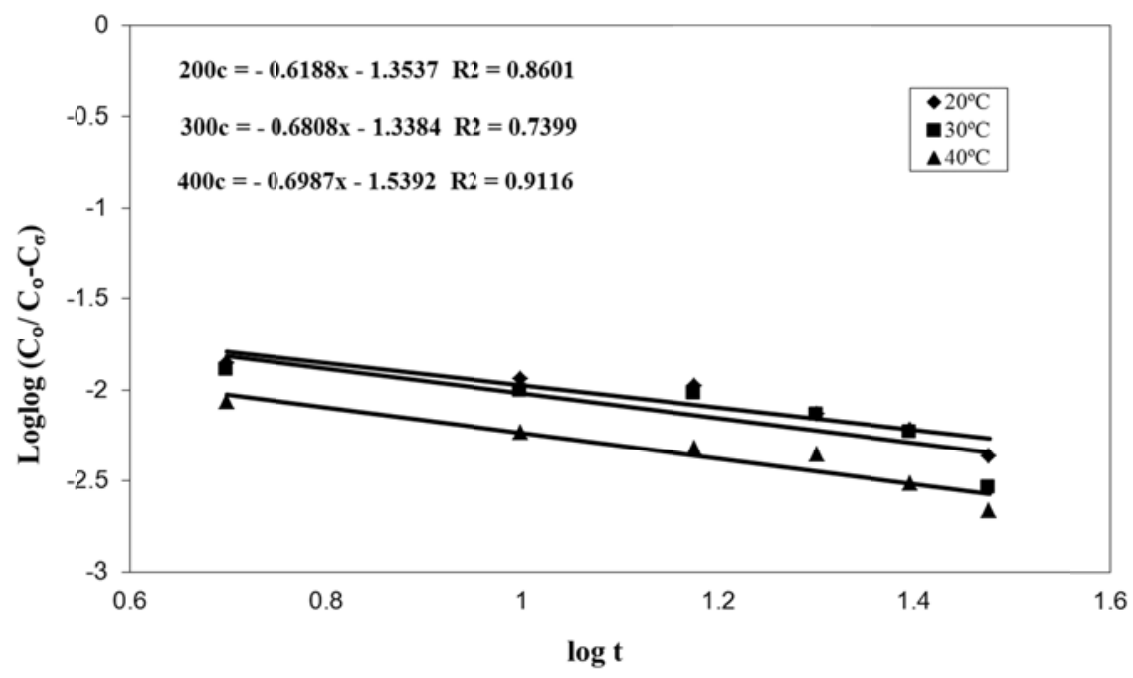

Figure 7. Bhangum plots for adsorption of oxalic acid on treated egg shells 


\subsubsection{Parabolic diffusion model (I ntraparticle diffusion)}

Our results show that plot of $C_{\varnothing}$ versus $\mathrm{t}^{1 / 2}$ indicates multi linearity, which describes the distinctive nature of different steps in the adsorption process ${ }^{[33]}$. According to Morris and Weber intra-particle diffusion:

$$
C_{\emptyset}=k_{i d} t^{1 / 2}+B
$$

The value of $k_{i d}$ was calculated by plotting $C_{\varnothing}$ against $t^{1 / 2}$ as shown in Figure 8 . The value of $\mathrm{R}^{2}$ of intra-particle diffusion adsorption is closer to 1 . The results are given in Table 5 and show the best coincidence to fit for the adsorption of oxalic acid ${ }^{[33,34]}$.

Table 5. Thermodynamic constants for adsorption of oxalic acid onto egg shells sample

\begin{tabular}{|c|c|c|c|c|c|c|c|c|c|c|c|}
\hline \multirow{2}{*}{ Acids } & \multirow{2}{*}{ Sample } & \multicolumn{3}{|c|}{$k\left(\min ^{-1}\right)$} & \multirow{2}{*}{$\begin{array}{l}\Delta \mathbf{E}^{\neq} \\
\left(\mathrm{kJ} \cdot \mathrm{mol}^{-1}\right)\end{array}$} & \multicolumn{3}{|c|}{$\Delta \mathbf{H}^{\ddagger}\left(\mathrm{kJ} \cdot \mathrm{mol}^{-1}\right)$} & \multicolumn{3}{|c|}{$\Delta \mathrm{S}^{\ddagger}\left(\mathrm{J} \cdot \mathrm{mol}^{-1} \mathrm{~K}^{-1}\right)$} \\
\hline & & $20^{\circ} \mathrm{C}$ & $30^{\circ} \mathrm{C}$ & $40^{\circ} \mathrm{C}$ & & $20^{\circ} \mathrm{C}$ & $30^{\circ} \mathrm{C}$ & $40^{\circ} \mathrm{C}$ & $20^{\circ} \mathrm{C}$ & $30^{\circ} \mathrm{C}$ & $40^{\circ} \mathrm{C}$ \\
\hline $\begin{array}{l}\text { Oxalic } \\
\text { acid }\end{array}$ & Treated & 0.0456 & 0.0532 & 0.0537 & 5.997 & 3.560 & 3.477 & 3.394 & -292.328 & -291.995 & -292.819 \\
\hline
\end{tabular}

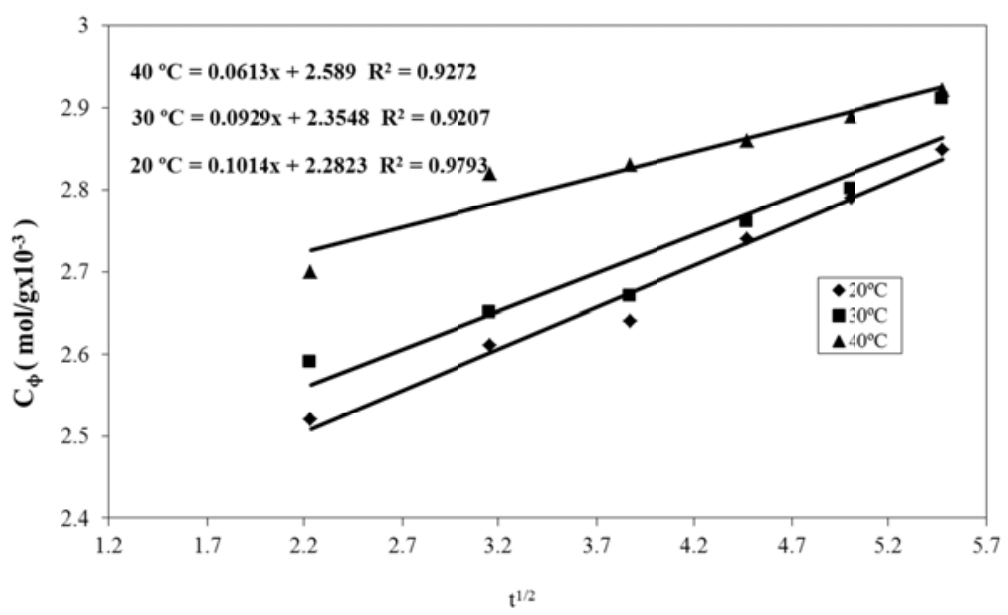

Figure 8. Intraparticle diffusion plots for adsorption of oxalic acid on treated egg shells

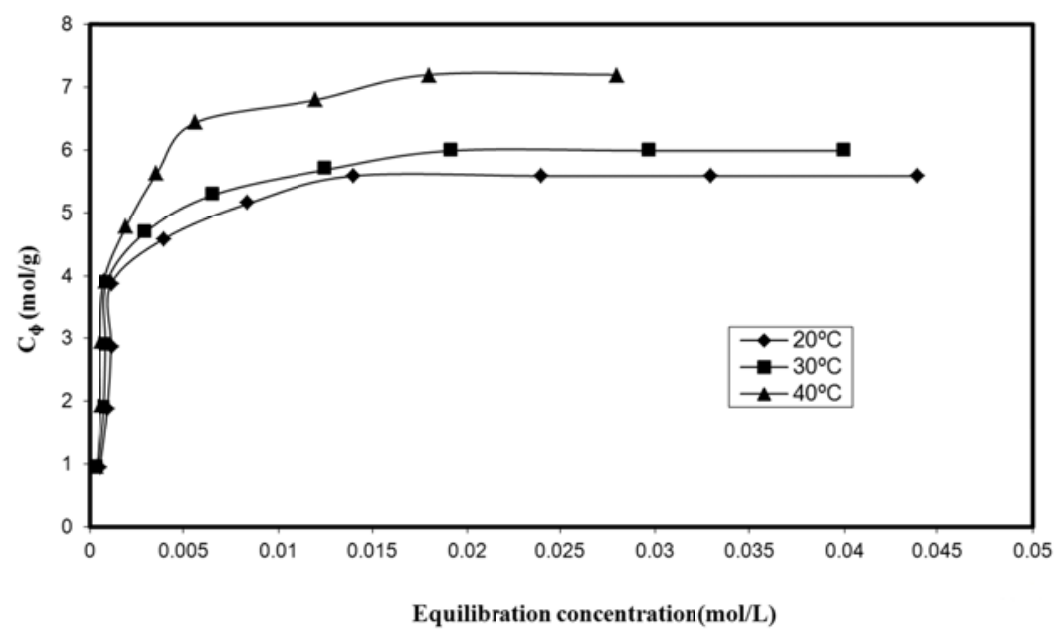

Figure 9. Adsorption isotherm for the adsorption of oxalic acid on treated egg shells sample 


\section{Adsorption isotherm studies}

Adsorption isotherms of oxalic acid on powder egg shell samples are shown in Figure 9. After equilibrium the graph becomes straight showing maximum adsorption and the adsorption of acid increases with increasing temperature. This high adsorption is mainly attributed to high surface area and large opening size in treated egg shell powder causing more interaction of acid molecules with the samples.

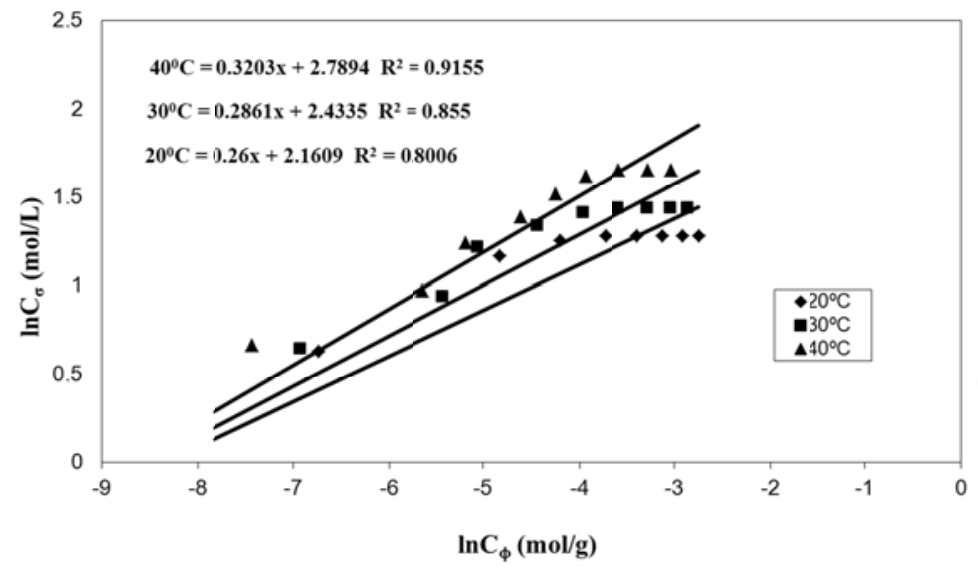

Figure 10. Freundlich isotherm plots for adsorption of oxalic acid on treated egg shells sample

\subsection{Freundlich isotherm}

The Freundlich isotherm plots for adsorption of oxalic acid on treated egg shells sample are shown in Figure 10. According to the linear form of Freundlich equation ${ }^{[35]}$ as given below:

$$
\ln C_{\sigma}=\ln \mathrm{k}+\frac{1}{n} \ln C_{\alpha}
$$

The values of $n$ and $k$ were obtained as given in Table 6. The constant value of $n$ gives information about the surface morphology and the ability of adsorbed solute particles ${ }^{[36,37]}$. The efficiency of adsorption increases with increasing $1 / n$ ratio. The value of $k\left(\mathrm{~mol} \cdot \mathrm{g}^{-1}\right)$ indicates the adsorption capacity of powder egg shells. It is clear from the given data in Table 6 that adsorption capacity of egg shell powder increases with increasing temperature.

Table 6. Comparison of adsorption isotherm constants of oxalic acid adsorption onto treated egg shells samples

\begin{tabular}{|c|c|c|c|c|}
\hline \multirow{2}{*}{ Isotherm } & \multirow{2}{*}{ Parameter } & \multicolumn{3}{|c|}{ Shaking Temperature } \\
\hline & & $20^{\circ} \mathrm{C}$ & $30^{\circ} \mathrm{C}$ & $40^{\circ} \mathrm{C}$ \\
\hline \multirow{3}{*}{ Freundlich } & $1 / \mathrm{n}$ & 0.3116 & 0.3149 & 0.3681 \\
\hline & $\mathrm{K}_{\mathrm{F}}(\mathrm{mg} / \mathrm{g})$ & 18.344 & 20.438 & 35.666 \\
\hline & $\mathrm{R}^{2}$ & 0.7056 & 0.7195 & 0.7335 \\
\hline \multirow{3}{*}{ Langmuir } & $\mathrm{b}(\mathrm{mg} / \mathrm{g})$ & 0.585 & 0.621 & 0.763 \\
\hline & $\mathrm{K}_{\mathrm{L}}(\mathrm{L} / \mathrm{mg})$ & 6.944 & 9.009 & 7.194 \\
\hline & $\mathrm{R}^{2}$ & 0.9975 & 0.9959 & 0.9962 \\
\hline \multirow{4}{*}{ Tempkin } & $\alpha\left(\mathrm{dm}^{3} / \mathrm{g}\right)$ & 139.491 & 155.866 & 111.944 \\
\hline & $\beta\left(\mathrm{mg} / \mathrm{dm}^{3}\right)$ & 0.9752 & 1.0339 & 1.3908 \\
\hline & $\mathrm{B}$ & 2498.463 & 2436.543 & 1871.068 \\
\hline & $\mathrm{R}^{2}$ & 0.8295 & 0.8538 & 0.9085 \\
\hline \multirow{3}{*}{ Harkins-jura } & A & 45.258 & 43.290 & 34.843 \\
\hline & $\mathrm{B}$ & 0.154 & 0.427 & 1.125 \\
\hline & $\mathrm{R}^{2}$ & 0.8781 & 0.9011 & 0.8634 \\
\hline
\end{tabular}




\subsection{Langmuir isotherm}

The linear form of this isotherm ${ }^{[38,39]}$ is given by:

$$
\frac{C_{\sigma}}{C_{\varnothing}}=\frac{1}{b k_{l}}+\frac{C_{\sigma}}{b}
$$

Where $b(\mathrm{~mol} / \mathrm{g})$ is the amount of adsorbed oxalic acid in complete monolayer coverage and $k_{l}(1 / \mathrm{g})$ is the binding energy constants. By plotting $C_{\sigma} / C_{\emptyset}\left(\mathrm{g} \cdot \mathrm{dm}^{-3}\right)$ against $C_{\sigma}$, a straight line was obtained as shown in the Figure 11 . From the plot the values of $b$ and $k$ were calculated as shown in Table 7. It is evident from the graph that adsorption capacity (b) of the adsorbent increases with increasing temperature. The regression coefficient $\mathrm{R}^{2}$ is close to 1 which shows that the Langmuir isotherm model is best fit for the adsorption of acids on egg shells adsorbent.

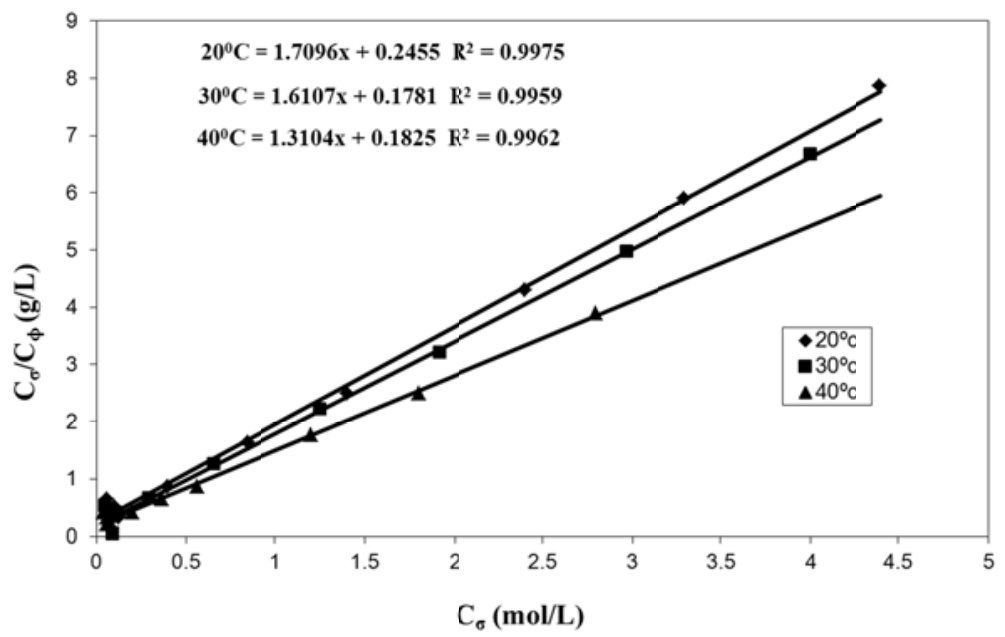

Figure 11. Langmuir isotherm plots for the adsorption of oxalic acid on treated egg shells

$\Delta G^{0}$ was calculated by the following equations (15):

$$
\Delta G^{o}=-R T \ln K_{t}
$$

where $b\left(\mathrm{~mol} \cdot \mathrm{g}^{-1}\right)$ is the capacity of Langmuir monolayer adsorption and $K_{t}=b M_{A}$, where $M_{A}$ is the molecular mass of acid. The obtained data is show in Table 7 . The negative values of $\Delta G^{o}$ show that adsorption on the surface of egg shell powder is spontaneous. It is clear that the values of Gibbs free energy decrease with increasing temperature indicating that the extent of adsorption increases with increasing temperature.

Table 7. Thermodynamic parameter $\Delta \mathrm{G}^{\mathrm{o}}$ for the adsorption of oxalic acid on treated egg shells samples

\begin{tabular}{lllll}
\hline \multirow{2}{*}{ Acid } & Sample & \multicolumn{4}{c}{$\Delta \mathbf{G}^{\mathbf{0}} \times \mathbf{1 0}^{\mathbf{2}}\left(\mathbf{k J} \cdot \mathbf{m o l}^{-1}\right)$} & $\mathbf{4 0}^{\circ} \mathbf{C}$ \\
\cline { 3 - 5 } & & $\mathbf{2 0}^{\circ} \mathbf{C}$ & $\mathbf{3 0}^{\circ} \mathbf{C}$ & -110.07 \\
\hline Oxalic acid & Treated & -96.56 & -101.37 & \\
\hline
\end{tabular}

\subsection{Tempkin isotherm}

The linear form of Tempkin isotherm model is given as ${ }^{[40]}$ :

$$
C_{\emptyset}=\beta \ln \alpha+\beta \ln C_{\sigma}
$$


By plotting $C_{\emptyset} v s . \ln C_{\sigma}, \alpha$ straight line was obtained with slope equal to $\beta$ and intercept equal to $\beta \ln \alpha$ as shown in Figure 12. The obtained values of $b$ are given in Table 6 . It is evident that the value of $b$ increases with increasing temperature.

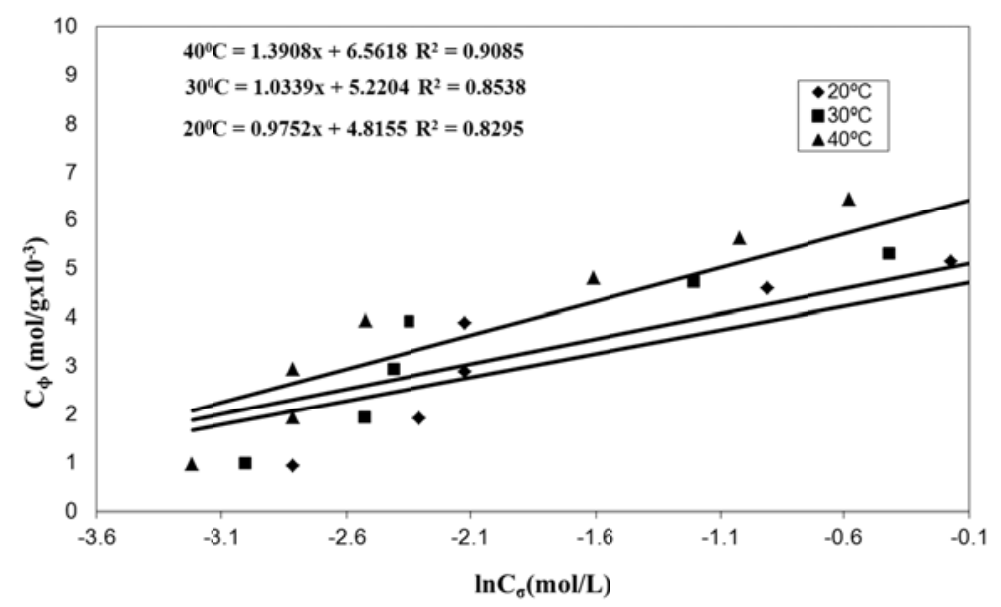

Figure 12. Tempkin isotherm plot for the adsorption of oxalic acid on treated egg shells sample

\subsection{Harkins-jura adsorption isotherm}

The equation of Harkins-jura adsorption isotherm ${ }^{[41]}$ is as follows:

$$
\frac{1}{\left(C_{\varnothing}\right)^{2}}=\frac{B}{A}-\frac{1}{A} \log C_{\sigma}
$$

By plotting $1 /\left(C_{\varnothing}\right)^{2}$ against $C_{\sigma}$, a straight line curve was obtained as shown in the Figure 13. The value of constant $A$ and $B$ were calculated from the intercept and slope of the curve and are shown in Table 6. It is clear that by increasing temperature, the values of $B$ also increase indicating the adsorption of oxalic acid on the surface of egg shell powder.

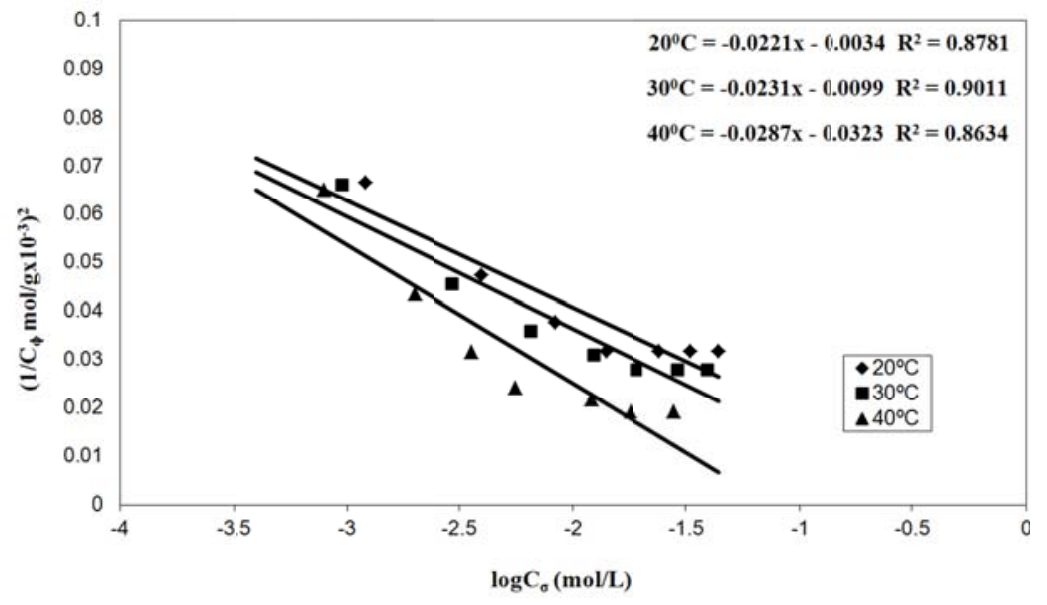

Figure 13. Harkins-jura isotherm plots for adsorption of oxalic acid on treated egg shells sample

\section{Conclusions}

We have successfully adsorbed oxalic acid on the surface of powder egg shell with pores of different size and shapes and surface area nearly equal to $273 \mathrm{~m}^{2} \cdot \mathrm{g}^{-1}$. Intra-particle diffusion, Elovich and Bhangam models were used for adsorption 
kinetics and thermodynamic parameters $\Delta \mathrm{H}^{\neq}, \Delta \mathrm{S}^{\neq}$and $\Delta \mathrm{E}^{\neq}$were calculated. Equilibrium time required for complete coverage of surface was about 2 hours. The experimental data shows that adsorption of acid on powder egg shell samples is best fitted to the linear equation and it was concluded that the process was diffusion control process and was spontaneous. Entropy of adsorption has negative value which shows that the acid molecules on the surface of adsorbent take an oriented position. Freundlich, Langmuir, Tempkin and Harkins-Jura linear equations were used to investigate adsorption isotherms. The results demonstrate that this work is suitable for waste water purification.

\section{Acknowledgments}

We are grateful for financial support from Malakand University KPK, Malakand, Pakistan.

\section{Conflicts of I nterest}

The authors declared no conflict of interest.

\section{References}

[1] Allien SJ, Koumanova B. Decolorization of water/waste water using adsorption. Chem Tech metal. 2005; 40: 145-92.

[2] Gezici O, Kara H, Ersoz M, et al. The behavior of nickel insolubilized humic acid system in a column arrangement. Collid Interface Sci. 2005; 292: 381-92. PMid:16188270. http://dx.doi.org/10.1016/j.jcis.2005.06.009

[3] Humayun M, Khan A, Zada A, et al. Synthesis and Physicochemical Characterization of ZnO-Porphyrin Based Hybrid Materials. J Chem Soc Pak. 2014; 36: 639-46.

[4] Khan A, Zada A, Humayun M. Physicochemical Interaction of ZnO Fine Particles with 5-Mono-(4-carboxyphenyl)-10,15,20Triphenylporphyrin. J Chin Chem Soc. 2015; 62: 915-24. http://dx.doi.org/10.1002/jccs.201400190

[5] Zhao X, Zhang J, Wang B, et al. Biochemical Synthesis of Ag/AgCl Nanoparticles for Visible-Light-Driven Photocatalytic Removal of Colored Dyes. J Materials. 2015; 8: 2043-53. http://dx.doi.org/10.3390/ma8052043

[6] Grosjean D, Cauwenberghe K, Schmid J, et al. Identification of C3-C10 aliphatic dicarboxylic acid in airborne particulate matter. Env Sci. 1978; 12: 313-7. http://dx.doi.org/10.1021/es60139a005

[7] Wasielewska M, Banel A, Zygmant B. Determination of selected organic acids in animal farm water sample by ion chromatography. Chem Eng appl. 2012; 3: 178-281.

[8] W. H. O. World health organization, International Standards for Drinking Water. 1971; 3rd Ed, Geneva, 39.

[9] Meski S, Ziani S, Khireddine H. Removal of lead ion by hydroxyllapaptite prepared from the egg shell. Chem Eng. 2010; 55: 3923-8.

[10] Gupta K. Carrot P, Carrott M, et al. Low cost adsorbents, growing approach to waste water treatment. Env Sci Technol. 2009; 39: 783-842. http://dx.doi.org/10.1080/10643380801977610

[11] Bosso S, Enzweiller J. Evaluation of heavy metal removal from aqueous solution onto scolecite. Water Res. 2002; 36: 795-800. http://dx.doi.org/10.1016/S0043-1354(02)00208-7

[12] Abbollino O, Aceto M, Malandrino M, et al. Adsorption of heavy metals on Na-montmorillonite, effect of $\mathrm{pH}$ and organic substances. Water Res. 2003; 37: 1619-27. http://dx.doi.org/10.1016/S0043-1354(02)00524-9

[13] Ghoul M, Bacquet M, Morcellete M. Uptake of heavy metals from synthetic aqueous solutions using modified PEI-silica gels. Water Res. 2003; 37: 729-34. http://dx.doi.org/10.1016/S0043-1354(02)00410-4

[14] Zhang A, Asankura T, Uchiyami G. The adsorption mechanism of uranium (VI) from sea water on a macroporous fibrous polymeric adsorbent containing amidoxime chelating functional group. Reactfucpolym. 2003; 57: 67-76.

[15] Carvalho J, Araujo J, Castro F. Altamative low cost adsorbent for water and waste water decontamination derived from egg shell waste-An overview. W. Bio. 2011; 2: 157-63.

[16] Stadelman W. Egg and Egg product. Food science and tech. 2000; 593-9.

[17] Poland A, Sheldon B. Altering the thermal resistance of food borne bacterial pathogens with an egg shell membrane waste product. Food prot. 2001; 649: 488-92.

[18] Tsai W, Yang J, Lai C, et al. Characterization and adsorption properties of egg shell and egg shell membrane towards model textile dyes. Chemosphere. 2006; 65: 1999-2008. PMid:16904727. http://dx.doi.org/10.1016/j.chemosphere.2006.06.074

[19] Cavalho J, Ribeiro A, Graca J, et al. Adsorption process onto an innovative eggshell-derived low-cost adsorbent in simulated effluent and real industrial effluents, In Proceedings of the 1st International Conference on Wastes. Solution Treatments and Opportunities. 2011: 12-4. 
[20] William J, Owen J. Egg science and technology, 4th edition, food product press New York. 1995.

[21] Riando E. Electric properties of polymers. Marcel Dekker. 2004: 121-5. http://dx.doi.org/10.1201/9781420030471

[22] Maski S, Ziani S, Khireddine H. Removal of lead ions by hydroxyapatite prepared from the egg shell. Chem Eng Data. 2010; 55: 3923-8. http://dx.doi.org/10.1021/je901070e

[23] Koumanova B, Peeva P, Allen S, et al. Biosorption from aqueous solutions by egg shell membranes and Rhizopusoryzae equilibrium and kinetic studies. Chem Tech Biotech. 2002; 77: 539-45. http://dx.doi.org/10.1002/jctb.601

[24] Tai W, Hsien K, Hsu H, et al. Utilization of ground egg shell waste as an adsorbent for the removal of dyes from aqueous solution. Bio Tech. 2008; 99: 1623-9. PMid:17543519. http://dx.doi.org/10.1016/j.biortech.2007.04.010

[25] Elwakeel K, Yousif M. Adsorption of malathion on thermally treated eggshell material. Proceeding of 14th International Water Technology Conference Cairo, Egypt. 2010: 53-65.

[26] Branton P, Hall P, Sing K, et al. Physisorption of Argon, Nitrogen and Oxygen by MCM-41, a Model Mesoporous Adsorbent. J Chem Soc Faraday Trans. 1994; 90: 2965-7. http://dx.doi.org/10.1039/FT9949002965

[27] Iqbal Y, Khan M, Ihsanuallah N. Effect of selected parameter on the adsorption of phenol on activated charcoal. Inter J Envi Studies. 2005; 62: 47-57. http://dx.doi.org/10.1080/0020723042000253875

[28] Cooke N, Fuller O, Gaikawad R. FT-IR spectroscopic analysis of coals and coal extracts. J Fuel. 1986; 65: 1254-9. http://dx.doi.org/10.1016/0016-2361(86)90238-3

[29] Laidler K. Chemical Kinetics, Mc-Graw Hill New York. 1965.

[30] Ren G, Zhao Z, Xiao H, et al. Biosorption of heavy metal ions from aqueous solution by an invasivealien plant Iva Xanthifolia Nutt biomass. Environ Mater and Environ Management. 2010; 113: 1464-7.

[31] Sharma K, Sharma L. A Text Book of physical chemistry, Vikas publishing House Pvt. Ltd. New Delhi. 1992: 493-4.

[32] Aharoni C, Sideman S, Hoffer E. Adsorption of Phosphate Ions by Collodion-Coated Alumina. Chem Technol Biotechnol. 1979; 29: 404-12. http://dx.doi.org/10.1002/jctb.503290703

[33] Tahir S, Rauf N. Thermodynamic studies of Ni(II) adsorption onto bentonite from aqueous solution. J Chem Thermodynamics. 2003; 35: 2003-9. http://dx.doi.org/10.1016/S0021-9614(03)00153-8

[34] Vandivelan V, Kumar K. Equilibrium, kinetics, mechanism, and process design for the sorption of methylene blue onto rice husk. Colloid Interf Sci. 2005; 286: 90-100. PMid:15848406. http://dx.doi.org/10.1016/j.jcis.2005.01.007

[35] Asheh Al, Duvnjak S. Sorption of cadmium and other heavy metals by pine bark. J Hazardous Materials. 1997 ; 56 : 35-51. http://dx.doi.org/10.1016/S0304-3894(97)00040-X

[36] Freundlich H. Colloid and Capillary Chemistry. E.P. Dutton and Co. New York. 1928.

[37] Hassler J. Purification with Activated Charcoal. Publishing CO., INC. New York. 1974; 356-70.

[38] $\mathrm{Ng} \mathrm{C}$, Losso J, Marshall W, et al. Freundlich adsorption isotherms of agricultural by-product-based powdered activated carbons in a geosmin-water system. Bio Technol. 2002; 85: 131-5. http://dx.doi.org/10.1016/S0960-8524(02)00093-7

[39] Wang S, Li H, Xu L. Application of zeolite MCM-22 for basic dye removal from wastewater. Colloid Inter Sci. 2006 ; $295: 71-8$. PMid:16143340. http://dx.doi.org/10.1016/j.jcis.2005.08.006

[40] Vickerstaff Y. The physical Chemistry of Dyeing, Inc, 100. 1954.

[41] Ferreior E, Bussetti D. Thermodynamic parameters of adsorption of 1, 10-phenanthroline and 2, 2/-bipyridyl on hematite, kaolinite and montmorillonites. Coll Surf A Physicocheml Engin Asp. 2007; 301: 117-28.

http://dx.doi.org/10.1016/j.colsurfa.2006.12.032 